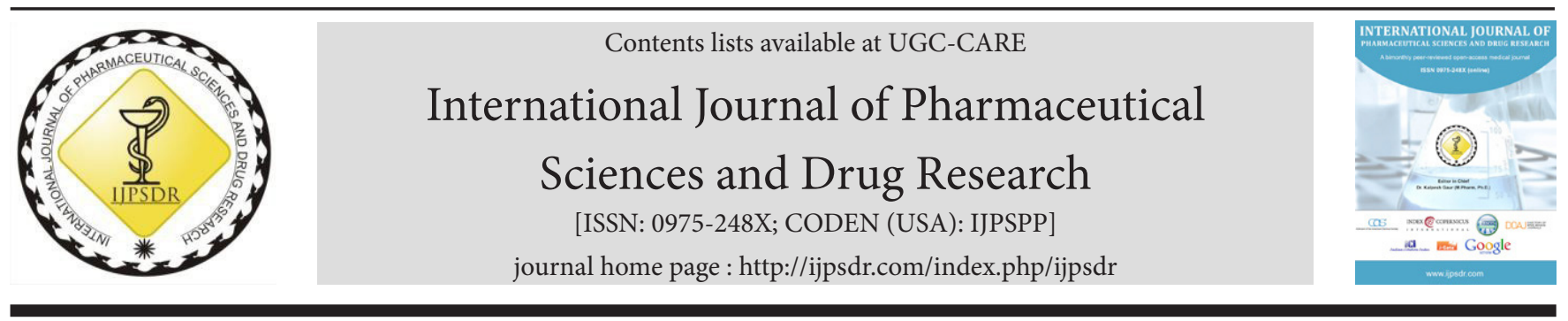

Research Article

\title{
A Structure Based Molecular Docking of Acacia Catechu Against Contractile Protein Plasmodium falciparum - A Malarial Disease
}

\author{
Abhishek Biswal R, Vivek Pazhamalai* \\ Department of Bio-Engineering, Vels Institute of Science Technology and Advanced Studies (VISTAS), Chennai- 600117, Tamil Nadu, India
}

\author{
A RT I CLE INFO \\ Article history: \\ Received: 02 November, 2019 \\ Revised: 12 January, 2020 \\ Accepted: 20 January, 2020 \\ Published: 30 January, 2020 \\ Keywords: \\ Acacia catechu, Contractile \\ protein, Malarial disease, \\ Molecular docking, Lasmodium \\ falciparum. \\ DOI: \\ 10.25004/IJPSDR.2020.120110
}

\begin{abstract}
A B S T R A C T
The bioactive compounds of Acacia catechu using gas chromatography-mass spectroscopy and the inhibitory activity against contractile protein Plasmodium falciparum against the protozoan disease were studied. This research mainly focuses on finding novel drug screening against the malarial enzyme. The compounds of Acacia catechu are screened using Lipinski rule of five with absorption distribution metabolism excretion (ADMET) properties in which the character, as well as behavior of the drug compound, is known. The compounds were checked for its dosage level in human and rat as well as distribution properties in the blood-brain barrier and central neuro system. The compounds 9,12,15Octadecatrienoic acid has a higher affinity with $-7.95 \mathrm{Kcal} / \mathrm{mol}$ followed by Phthalic acid, butyl 2- pentyl ester -7.35 Kcal/mol and Furo[2,3-d] Pyrimidine-4,6 [5H,7H]-dion -6.24 Kcal/mol were docked using Autodock software. The compound 9,12,15- Octadecatrienoic acid, Phthalic acid butyl 2- pentyl ester, Furo[2,3-d] Pyrimidine-4,6 [5H,7H]-dion has higher affinity such as $-7.95 \mathrm{Kcal} / \mathrm{mol},-7.35 \mathrm{Kcal} / \mathrm{mol}$ and $-6.24 \mathrm{Kcal} / \mathrm{mol}$, respectively. Thus this research proves that the drug compounds of Acacia catechu have novel therapeutic drug activity against virulent enzymes.
\end{abstract}

\section{INTRODUCTION}

Actin is the favorable macromolecule of microfilaments that mainly possess essential roles in central processes within the cell system, as well as transport, cellular division, and motility. The first biological activity of simple protein is its chemical process to create filaments that may generate force at cell membranes or act as staging structures or tracks for motor proteins. ${ }^{[1,2]}$ These filaments area unit on a timer supported the reaction of tightly certain nucleotide, the formation of intermediate ADP that is an inorganic phosphate (Pi) simple protein, and at last, the discharge of Pi. The physiological tightly certain power ion coordinating the certain ester in simple protein is $\mathrm{Mg}^{2+}$. However, simple protein is sometimes pure within the calcium-bound category that features a higher crucial concentration of chemical process. ${ }^{[3,4]}$ The actins present in plasmodium have short filaments that contain a noncanonical link between nucleotide molecules; however, some microfilaments that constrain structural factors are unknown. The situation of this supermolecule contains metallic ions throughout the reaction by exploiting the phosphate cluster that correlates with three-letter amino acids like essential amino acid, lysine, and amino alkanoic acid and essential amino acid. ${ }^{[5]}$ The loops of the tertiary supermolecule square measure are mainly connected with the simple protein protomer that links the inner and outer domain. Sarcomeres square measure divided into units that square measure derived by I bands and also the unit of measurement bisected by $\mathrm{Z}$ discs and $\mathrm{A}$ bands with a dark $\mathrm{M}$ in the middle. I bands accommodate skinny protein filaments, tropomyosin, and troponin. Thick filaments unit of measurement created from simple protein. ${ }^{[6]}$ The A band consists of overlapping skinny with thick filaments and various proteins. Acacia catechu (Wild or

\footnotetext{
*Corresponding Author: Mr. Vivek Pazhamalai

Address: Department of Bio-Engineering, Vels Institute of Science Technology and Advanced Studies (VISTAS), Chennai- 600117, Tamil Nadu, India Email $\square$ : viveksncet2011@gmail.com

Relevant conflicts of interest/financial disclosures: The authors declare that the research was conducted in the absence of any commercial or financial relationships that could be construed as a potential conflict of interest.

Copyright (C) 2020 Abhishek Biswal R et al. This is an open access article distributed under the terms of the Creative Commons AttributionNonCommercial-ShareAlike 4.0 International License which allows others to remix, tweak, and build upon the work non-commercially, as long as the author is credited and the new creations are licensed under the identical terms.
} 
Khair) belongs to a family Mimosaceae, this plant contains herbal remedies and is used as ayurvedic medicine. The medicinal character in plant helps to cure stomach and gastrointestinal diseases. Antioxidant properties are also reported from both extract (Wild and Khair) rather than an anti-cognitive disorder, anti-acetylcholinesterase, and anti-schizophrenic reports were not available. ${ }^{[7]}$

\section{Phytochemical screening}

The biochemical studies show the presence of phytochemicals like resins, saponins, flavonoids, alkaloids, steroids, glycosides, protein, and carbohydrate. ${ }^{[8,9]}$ The physiochemical parameters like ask content, soluble acid ash, water-soluble ash, water-soluble extractives, volatile oil, fiber content, and total sugar were analyzed in which various factors like $\mathrm{CO}_{3}{ }^{2-}, \mathrm{PO}_{4}{ }^{3-}, \mathrm{SO}_{4}{ }^{2-}, \mathrm{AL}^{3+}, \mathrm{Ca}^{2+}, \mathrm{Mg}^{2+}$, and $\mathrm{K}^{+}$were found to be positive. ${ }^{[10]}$ The flavonoids and the tannins present in the plant plays a major role as an inhibitory factor against virulent enzymes. This plant has fluorescence behavior of different extracts of Acacia catechu with extractives like petroleum ether, benzene, acetone, etc. ${ }^{[11]}$

\section{MATERIALS AND METHODS}

Biologically Active Compounds of Acacia Catechu by Using Gas Chromatography-Mass Spectrometry (GCMS) The biologically active compounds of the Acacia catechu were analyzed using GCMS, and the peaks were compared using WILEY and NIST libraries. The major components found in the hydroethanolic leaf extract were Benzenamine, 3 ethoxy, 2Methyl-1,2,3,4-tetrahydro betacarboline, 1-Methoxy-4-(4-Methoxy benzene), 2-napthalenamine, phthalic acid, 6-ethyl-3-octyl butyl ester, phthalic acid, butyl 2-pentyl ester, hexadecanoic acid, ethyl ester, 12-methoxy19-norpo docarpa, furo[2,3-d] pyrimidine-4,6

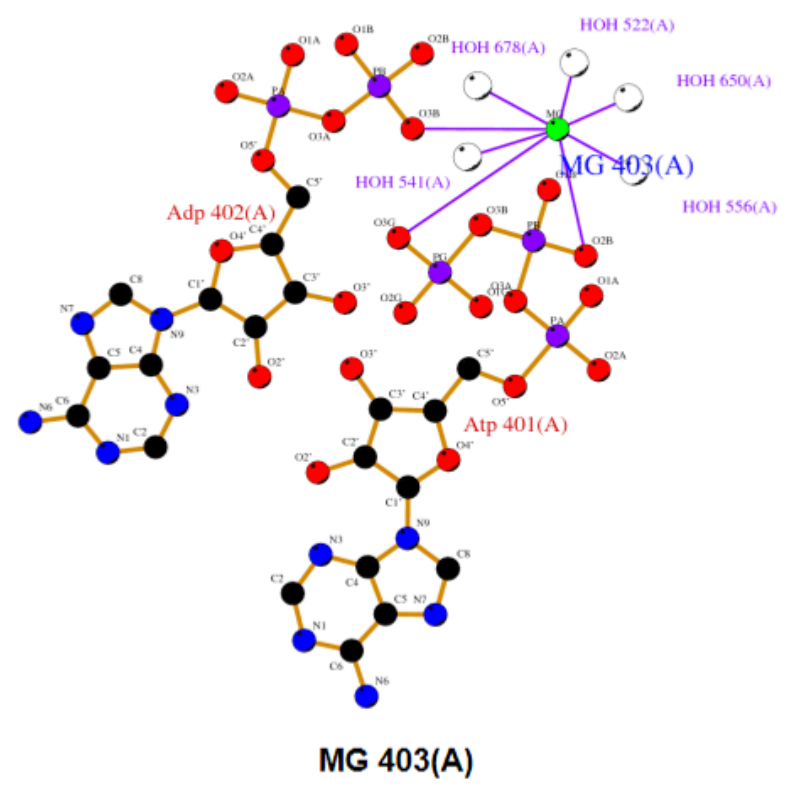

[5H,7H]-dion, Phytol 9,12,15-octadecatrienoic acid, butylphosphoric acid, di(4-methoxy benzene) and 2-pyridine carbonitrile, $1,2,5,6$. $^{[12]}$ The phytocompounds have better antioxidant activities against several diseases due to the presence of various phytochemicals. The compounds were analyzed using the Lipinski rule of five in which various parameters were checked like hydrogen bond acceptor and donor, molecular weight, lipophilicity and molar refractivity.

\section{Preparation of Contractile Protein}

The three-dimensional (3-D) structure of the contractile protein were taken from the protein data bank ID is 6I4L as shown in Fig. 1 with active site presentation. The protein, along with actin, is responsible for causing disease like Plasmodium falciparum that consists of virulent malarial strain. This disease plays an important role in suppressing the immunity system by interfering with phagocytic functions of macrophage. The contractile protein gets precipitated at pH 5 in which the malaria strain gets activated in smooth muscles. The protein stored in the database is at a resolution of $1.83 \AA$ at X-ray diffraction method. The protein mainly consists of A chain comprises of 378 amino acids. The three-letter coding active sites of amino acids in Plasmodium falciparum are shown in Fig. 1. The sequence of amino acid in protein is mainly responsible for stabilizing the macromolecules of the mutant protein to induce the protozoan enzyme. ${ }^{[13,14]}$

\section{Absorption Distribution Metabolism Excretion ADMET Properties}

The physiochemical properties like ADMRT were screened with the bioactive compounds of Acacia catechu determined from GCMS. These property plays a major role to analyze the behavior and characteristic of drug materials like water absorption level, gastrointestinal

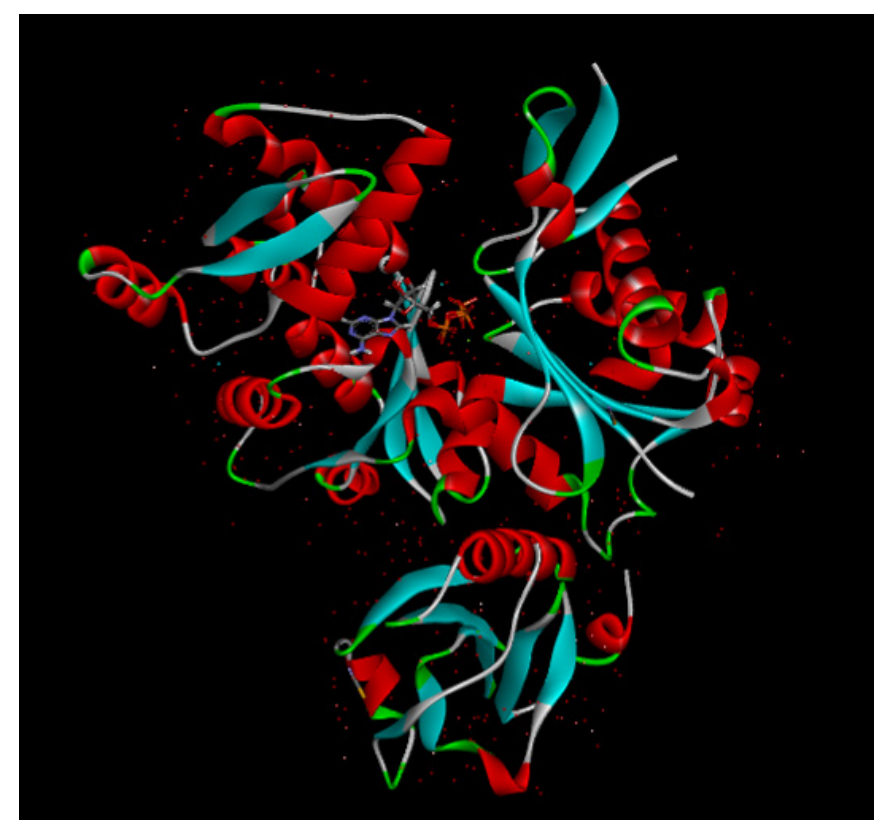

Fig. 1: Three letter coding active sites of amino acids 
absorption, the penetration level of drug molecules in the central nervous system, and blood-brain barrier. The hepatoprotective and skin permeability measures were also analyzed for both humans and rats. The ADMET properties were analyzed using the software http://www. sib.swiss for calculating the behavior of drug compounds that directly based on the principle of the vector-based algorithm. ${ }^{[15,16]}$

\section{Molecular Docking Using Autodock 4.2.6}

The software Autodock 4.2.6 is mainly used for proteinligand docking in which compounds will be rigid like structure. The parameters utilized for the process of docking will be a genetic algorithm in which the output file format will be of the Lamarckian genetic algorithm. The software can able to perform protein-protein interactions and ligand-protein interactions for showing better potential activity against virulent enzymes. The grid points for the total map were 64,000 , with grid spacing $0.375 \AA$ (default). The grid size set as default was $20 \AA$. The center grid box sizes in the protein sequence were centered as x center: -16.302 , y center: -23.34 , and -16.245 , respectively.

\section{RESULTS AND Discussion}

The biologically active compounds of Acacia catechu were confirmed using Lipinski rule of five to determine the drug properties. The bioactive compound that satisfies the lipinski rule of five are benzenamine, 3-ethoxy, 12-methoxy19-norpo docarpa, furo[2,3-d] pyrimidine-4,6 [5h,7h]-dion, 2methyl-1,2,3,4-tetrahydro beta-carboline, 1-methoxy-4-(4-methoxy benzene), phthalic acid, butyl 2-pentyl ester, 9,12,15-octadecatrienoic acid, butylphosphoric acid, di(4-methoxy benzene) and 2-pyridine carbonitrile, 1,2,5,6 are listed in Table 1.

\section{Absorption Distribution Metabolism Excretion (ADMET) Properties}

The compounds that mainly satisfy the Lipinski rule of five were screened for ADMET for better identification of potential activity. The absorption properties of the drug were analyzed in which the water solubility of the drug molecule, glycoprotein inhibitor and substrate, gastrointestinal absorption, and skin permeability was shown in Table 2. The distribution properties that include the permeability level of the blood-brain barrier (BBB) and central nervous system (CNS) were shown in Table 3. The metabolism properties of the drug compounds have betterpromising parameters under cytochrome $\mathrm{p} 450$ which, as shown in Table 4. The excretion and toxicity level was analyzed in which the dosage level of the drug compound was tabulated in Tables 5 and 6 along with hepatotoxicity test and skin sensation. ${ }^{[15-17]}$

\section{Molecular Docking Studies}

The docking analysis was done against virulent enzyme Plasmodium falciparum, which was compared with the

Table 1: Compounds analyzed in lipinski rule of five

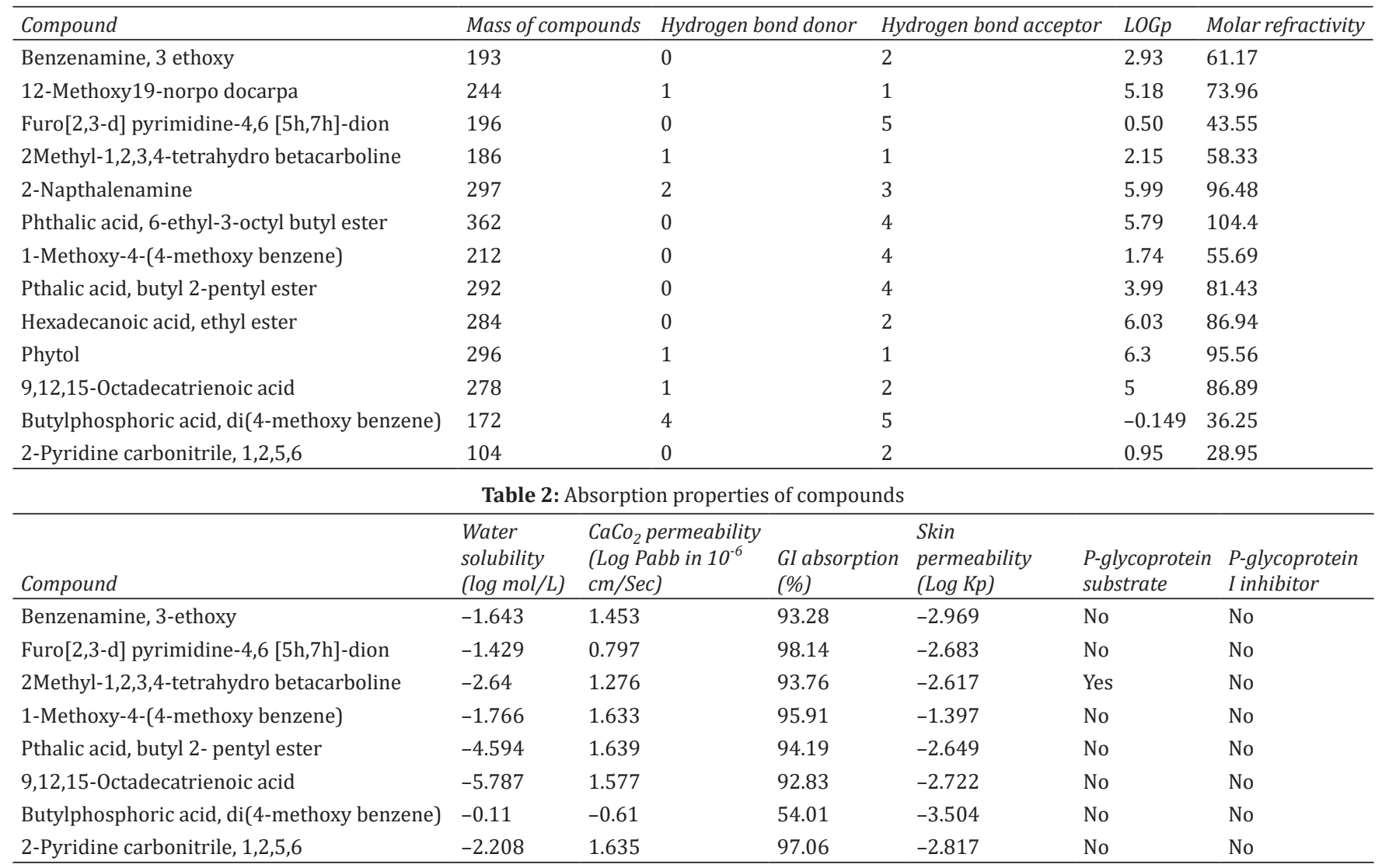


A Structure Based Molecular Docking of Acacia Catechu Against Contractile Protein Plasmodium falciparum - A Malarial Disease

Table 3: Distribution properties of compounds

\begin{tabular}{|c|c|c|c|c|}
\hline Compounds & $\begin{array}{l}\text { VDss (human) } \\
\text { (Log L/ } / \mathrm{kg})\end{array}$ & $\begin{array}{l}\text { Fraction unbound } \\
\text { (human) (Fu) }\end{array}$ & $\begin{array}{l}\text { BBB permeability (Log } \\
B B)\end{array}$ & $\begin{array}{l}\text { CNS permeability } \\
(\log P S)\end{array}$ \\
\hline Benzenamine, 3-ethoxy & 0.322 & 0.463 & 0.324 & -2.139 \\
\hline Furo[2,3-d] pyrimidine- $4,6[5 \mathrm{~h}, 7 \mathrm{~h}]$-dion & -0.343 & 0.614 & -0.638 & -2.92 \\
\hline 2Methyl-1,2,3,4-tetrahydro betacarboline & 0.914 & 0.375 & 0.356 & -1.491 \\
\hline 1- Methoxy-4-(4-methoxy benzene) & 0.166 & 0.382 & 0.469 & -1.814 \\
\hline Pthalic acid, butyl 2- pentyl ester & 0.053 & 0.107 & -0.066 & -2.406 \\
\hline 9,12,15- Octadecatrienoic acid & -0.617 & 0.056 & -0.115 & -1.547 \\
\hline Butylphosphoric acid, di(4-methoxy benzene) & -0.708 & 0.746 & -1.135 & -3.941 \\
\hline 2-Pyridine carbonitrile, 1,2,5,6 & -0.207 & 0.638 & -0.277 & -2.746 \\
\hline
\end{tabular}

Table 4: Metabolism properties of compounds

\begin{tabular}{|c|c|c|c|c|c|c|c|}
\hline Compound & $\begin{array}{l}\text { CYP2D6 } \\
\text { substrate }\end{array}$ & $\begin{array}{l}\text { CYP3A4 } \\
\text { substrate }\end{array}$ & $\begin{array}{l}\text { CYP1A2 } \\
\text { inhibitor }\end{array}$ & $\begin{array}{l}\text { CYP2C19 } \\
\text { inhibitor }\end{array}$ & $\begin{array}{l}\text { CYP2C9 } \\
\text { inhibitor }\end{array}$ & $\begin{array}{l}\text { CYP2D6 } \\
\text { inhibitor }\end{array}$ & $\begin{array}{l}\text { CYP3A4 } \\
\text { inhibitor }\end{array}$ \\
\hline Benzenamine, 3-ethoxy & No & No & No & No & No & No & No \\
\hline Furo[2,3-d] pyrimidine- $4,6[5 \mathrm{~h}, 7 \mathrm{~h}]$-dion & No & No & No & No & No & No & No \\
\hline 2Methyl-1,2,3,4-tetrahydro betacarboline & Yes & Yes & Yes & No & No & Yes & Yes \\
\hline 1-Methoxy-4-(4-methoxy benzene) & No & No & No & No & No & No & No \\
\hline Phthalic acid, butyl 2-pentyl ester & No & Yes & Yes & Yes & No & No & No \\
\hline 9,12,15-Octadecatrienoic acid & No & Yes & Yes & No & No & No & Yes \\
\hline Butylphosphoric acid, di(4-methoxy benzene) & No & No & No & No & No & No & No \\
\hline 2-Pyridine carbonitrile, 1,2,5,6 & No & No & No & No & No & No & No \\
\hline
\end{tabular}

Table 5: Toxicity and excretion properties of compounds

\begin{tabular}{|c|c|c|c|c|c|c|c|c|}
\hline Compound & $\begin{array}{l}\text { Renal } \\
\text { OCT2 } \\
\text { substrate }\end{array}$ & $\begin{array}{l}\text { AMES } \\
\text { toxicity }\end{array}$ & $\begin{array}{l}\text { Max. tolerated } \\
\text { dose (human) } \\
\text { (Log } \mathrm{mg} / \mathrm{kg} / \\
\text { day) }\end{array}$ & $\begin{array}{l}\text { hERG I } \\
\text { inhibitor }\end{array}$ & $\begin{array}{l}\text { Oral rat } \\
\text { acute } \\
\text { toxicity } \\
(\mathrm{LD} 50) \\
(\mathrm{mol} / \mathrm{kg})\end{array}$ & $\begin{array}{l}\text { Oral rat } \\
\text { chronic } \\
\text { toxicity } \\
(L O A E L) \\
(L o g \mathrm{mg} / \mathrm{kg})\end{array}$ & $\begin{array}{l}\text { Liver } \\
\text { Toxicity }\end{array}$ & $\begin{array}{l}\text { Skin } \\
\text { sensitization }\end{array}$ \\
\hline Benzenamine, 3 ethoxy & No & No & 0.548 & No & 2.201 & 1.735 & No & Yes \\
\hline Furo[2,3-d] pyrimidine- $4,6[5 \mathrm{~h}, 7 \mathrm{~h}]$-dion & No & No & 1.361 & No & 2.765 & 2.111 & Yes & No \\
\hline 2Methyl-1,2,3,4-tetrahydro beta-carboline & Yes & Yes & -0.018 & No & 2.76 & 1.603 & No & Yes \\
\hline 1- Methoxy-4-(4-methoxy benzene) & No & No & 0.905 & No & 1.822 & 2.007 & No & Yes \\
\hline Phthalic acid, butyl 2- pentyl ester & No & No & 1.531 & No & 1.748 & 2.384 & No & No \\
\hline 9,12,15- Octadecatrienoic acid & No & No & -0.84 & No & 1.441 & 3.115 & Yes & Yes \\
\hline Butylphosphoric acid, di(4-methoxy benzene) & No & No & 1.555 & No & 1.943 & 2.25 & No & No \\
\hline 2-Pyridine carbonitrile, 1,2,5,6 & No & No & 1.092 & No & 2.336 & 1.603 & No & Yes \\
\hline
\end{tabular}

standard drug as control. When compared with standard drug the bioactive compounds have a high affinity towards the virulent enzymes. The binding energy of each ligand molecule is listed along with the types of interactions like hydrogen and vander Waals interaction. The active site of the enzymes was docked in which the compound 9, 12, 15-octadecatrienoic acid has higher affinity with $-7.95 \mathrm{Kcal} / \mathrm{mol}$ followed by Phthalic acid, butyl 2-pentyl ester $-7.35 \mathrm{Kcal} / \mathrm{mol}$ and Furo [2,3-d] pyrimidine-4,6 $[5 \mathrm{H}, 7 \mathrm{H}]$-dion $-6.24 \mathrm{Kcal} / \mathrm{mol}$. The total number of residues interacted between ligand and virulent protein are LYS 19, ASN 17, GLY 16, ASP 158, GLY 303, GLY 302, VAL 340, ASP 155, GLY 14, SER 15, GLY 159, TYR 338, GLY 157, VAL 31, GLN 138, LYS 337, GLY 308, LYS 19, SER 15, ASP 158, ASN 17, GLY 14, GLY 16, ARG 336, SER 142, SER 301, SER 339,
LYS 337, TYR 338, ASP 12, ASP 155, VAL 340, HIS 162, GLY 157, SER 161, VAL 160, GLY 75, GLY 302, SER 136, GLY 129, HIS 162, GLN 138, SER 15, ASP 158, ASN 13, ALA 109, GLY 75, PRO 110, ASP 155, ALA 139, SER 161, VAL 160, SER 156, GLY 157, GLY 16, GLY 159, ASN 13. Acacia catechu has greater inhibitory activity against malaria disease by interfering with a normal habitat of the human body. These compounds do not have any toxic factors which have been evaluated using Lipinski rule of five and ADMET properties. The Table 6 and Figs. 2 to 4 shows detailed information about the active amino acids involved in structure-based drug design with pictorial representation. The structure-based drug design strategy plays a major role in designing the potential drug against the virulent protein. 

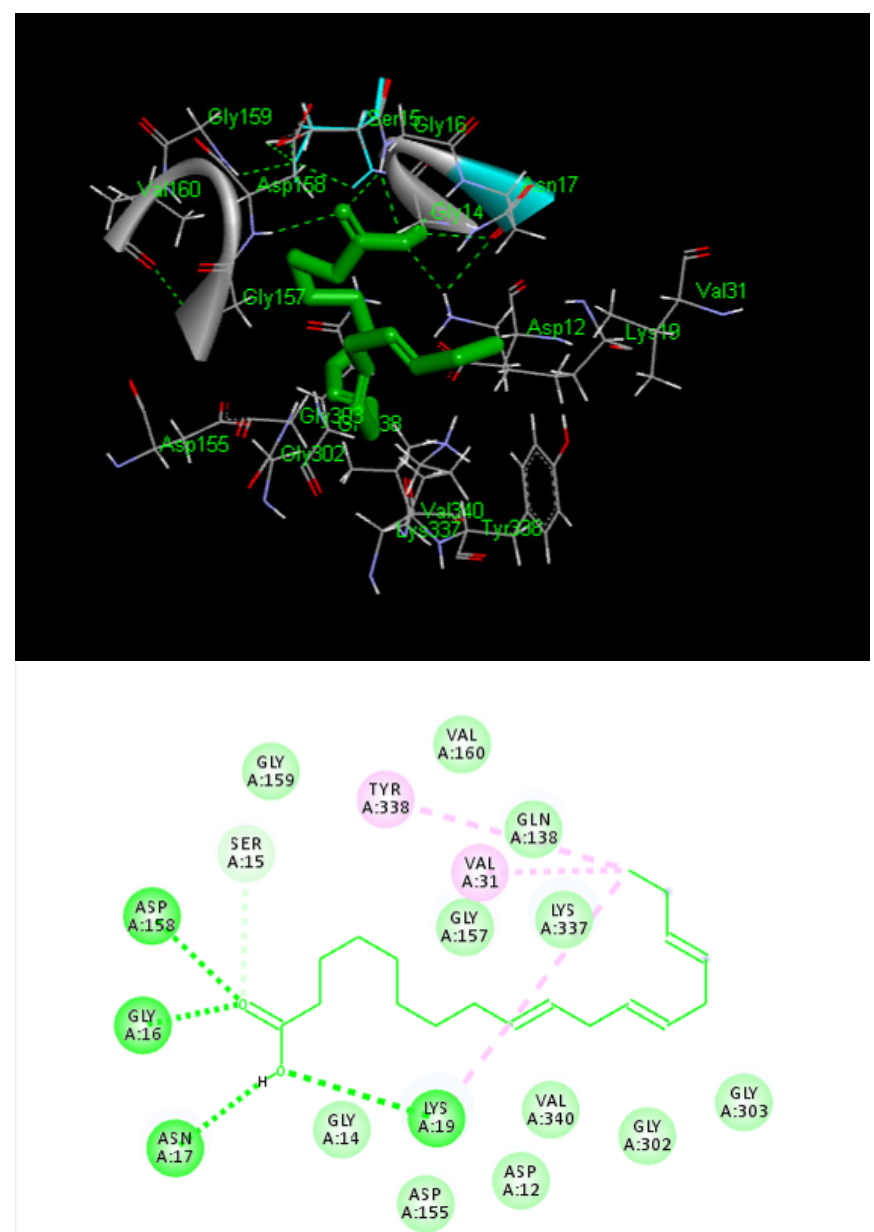
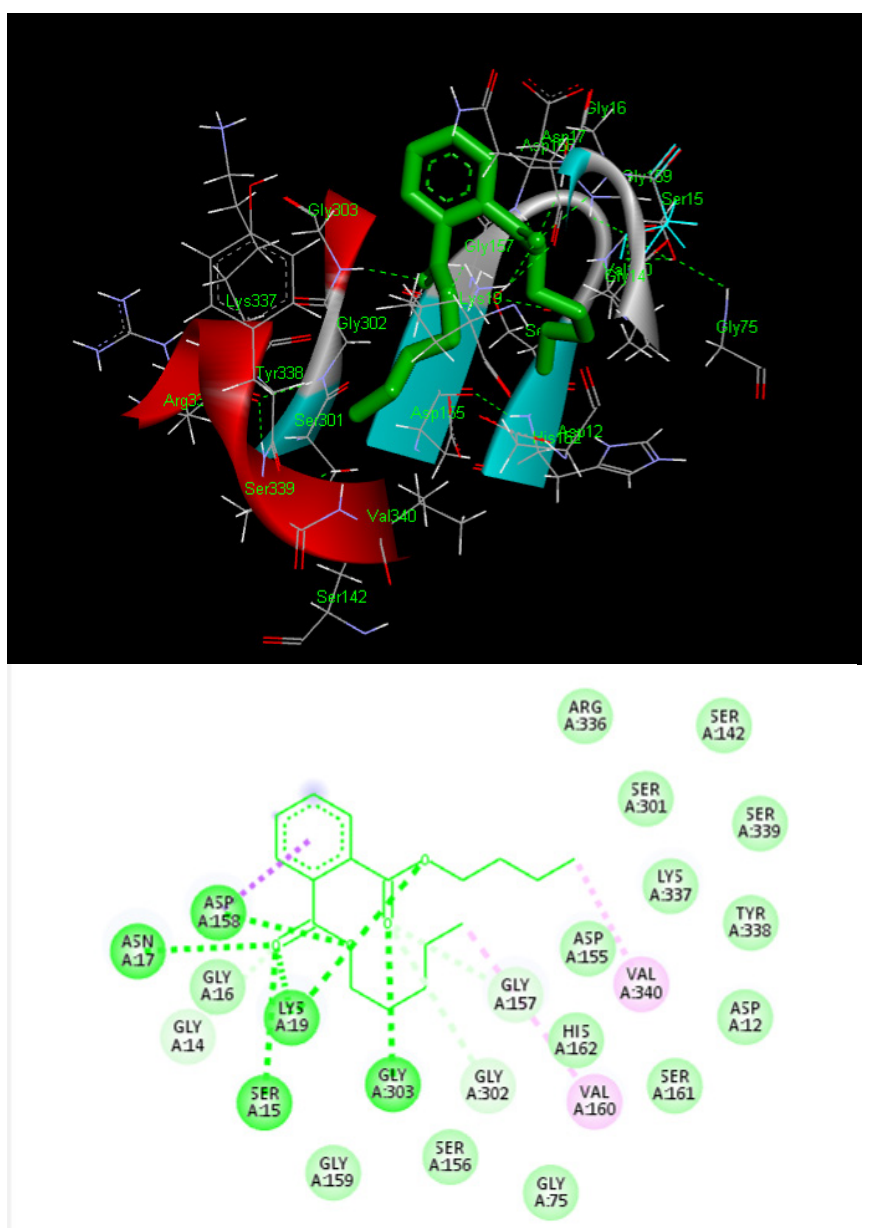

Fig. 2: 2D and 3D interactions of 9,12,15-octadecatrienoic acid

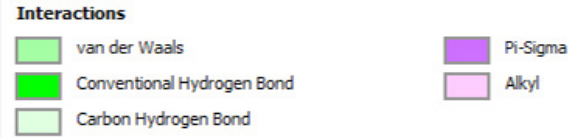

Fig. 3: 2D and 3D interactions of phthalic acid, butyl 2-pentyl ester

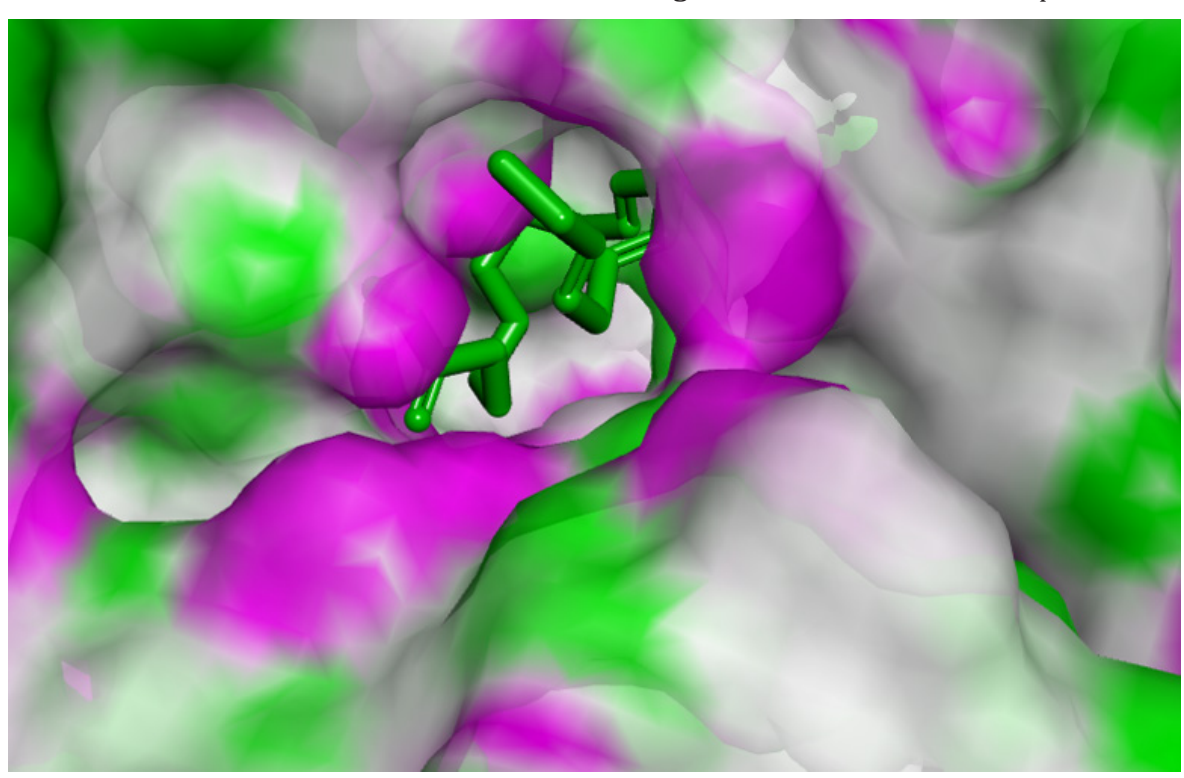

Fig. 4: Surface image of 9,12,15-octadecatrienoic acid 
Table 6: Interactions of various bioactive compounds

\begin{tabular}{|c|c|c|c|c|c|}
\hline Compound & $\begin{array}{l}\text { Binding energy } \\
\mathrm{Kcal} / \mathrm{mol}\end{array}$ & $\begin{array}{l}\text { Vanderwaals } \\
\text { interaction }\end{array}$ & $\begin{array}{l}\text { No. of hydrogen } \\
\text { bonds }\end{array}$ & $\begin{array}{l}\text { Hydrogen } \\
\text { interactions }\end{array}$ & Total no. of residues \\
\hline Benzenamine, 3-ethoxy & -5.17 & $\begin{array}{l}\text { ASP 155, LYS 19, ASN 17, ASP } \\
\text { 158, GLY 16, GLY 14, GLY 157, } \\
\text { GLY 159, GLY 75, ASN 13, } \\
\text { GLN 138, SER 161, HIS 162, } \\
\text { VAL } 160\end{array}$ & 1 & SER 15 & $\begin{array}{l}\text { SER 15, ASP 155, LYS 19, ASN 17, } \\
\text { ASP 158, GLY 16, GLY 14, GLY 157, } \\
\text { GLY 159, GLY 75, ASN 13, GLN 138, } \\
\text { SER 161, HIS 162, VAL } 160\end{array}$ \\
\hline $\begin{array}{l}\text { Furo[2,3-d] } \\
\text { Pyrimidine-4,6 } \\
{[5 \mathrm{H}, 7 \mathrm{H}] \text {-dion }}\end{array}$ & -6.24 & $\begin{array}{l}\text { ASN 13, ALA 109, GLY 75, } \\
\text { PRO 110, ASP 155, ALA 139, } \\
\text { SER 161, VAL 160, SER 156, } \\
\text { GLY 157, GLY 16, GLY 159, } \\
\text { ASN } 13\end{array}$ & 4 & $\begin{array}{l}\text { HIS 162, GLN } \\
138, \text { SER 15, ASP } \\
158\end{array}$ & $\begin{array}{l}\text { HIS 162, GLN 138, SER 15, ASP 158, } \\
\text { ASN 13, ALA 109, GLY 75, PRO 110, } \\
\text { ASP 155, ALA 139, SER 161, } \\
\text { VAL 160, SER 156, GLY 157, GLY 16, } \\
\text { GLY 159, ASN } 13\end{array}$ \\
\hline $\begin{array}{l}2 \text { Methyl-1,2,3,4- } \\
\text { tetrahydro } \\
\text { betacarboline }\end{array}$ & -6.23 & $\begin{array}{l}\text { TYR 338, GLY 302, GLY 157, } \\
\text { VAL 160, ASP 158, SER 15, } \\
\text { GLY 75, GLY 14, LYS 19, } \\
\text { ASN 133, GLN 138, THR 107, } \\
\text { VAL 340, LYS } 337\end{array}$ & 1 & ASP 12 & $\begin{array}{l}\text { ASP } 12 \text {, TYR } 338 \text {, GLY 302, GLY 157, } \\
\text { VAL 160, ASP 158, SER 15, GLY 75, } \\
\text { GLY 14, LYS 19, ASN 133, GLN 138, } \\
\text { THR } 107, \text { VAL } 340 \text {, LYS } 337\end{array}$ \\
\hline $\begin{array}{l}\text { 1-methoxy-4-(4- } \\
\text { Methoxy benzene) }\end{array}$ & -5.41 & $\begin{array}{l}\text { GLY 157, ASN 13, GLN 138, } \\
\text { GLY 75, VAL 160, GLY 159, } \\
\text { GLY 14, ASP 158, GLY 16, } \\
\text { ASN 17, TYR 338, GLY 303, } \\
\text { THR 304, GLY } 302\end{array}$ & 2 & SER 15, LYS 19 & $\begin{array}{l}\text { SER 15, LYS 19, GLY 157, ASN 13, } \\
\text { GLN 138, GLY 75, VAL 160, GLY 159, } \\
\text { GLY 14, ASP 158, GLY 16, ASN 17, } \\
\text { TYR 338, GLY 303, THR 304, } \\
\text { GLY } 302\end{array}$ \\
\hline $\begin{array}{l}\text { Pthalic acid, butyl 2- } \\
\text { pentyl ester }\end{array}$ & -7.39 & $\begin{array}{l}\text { GLY 14, GLY 16, ARG 336, } \\
\text { SER 142, SER 301, SER 339, } \\
\text { LYS 337, TYR 338, ASP 12, } \\
\text { ASP 155, VAL 340, HIS 162, } \\
\text { GLY 157, SER 161, VAL 160, } \\
\text { GLY 75, GLY 302, SER 136, } \\
\text { GLY } 129\end{array}$ & 5 & $\begin{array}{l}\text { GLY } 308, \text { LYS 19, } \\
\text { SER 15, ASP 158, } \\
\text { ASN } 17\end{array}$ & $\begin{array}{l}\text { GLY 308, LYS 19, SER 15, ASP 158, } \\
\text { ASN 17, GLY 14, GLY 16, ARG 336, } \\
\text { SER 142, SER 301, SER 339, LYS } \\
\text { 337, TYR 338, ASP 12, ASP 155, VAL } \\
\text { 340, HIS 162, GLY 157, SER 161, } \\
\text { VAL 160, GLY 75, GLY 302, SER 136, } \\
\text { GLY } 129\end{array}$ \\
\hline $\begin{array}{l}9,12,15- \\
\text { octadecatrienoic acid }\end{array}$ & -7.95 & $\begin{array}{l}\text { GLY 303, GLY 302, VAL 340, } \\
\text { ASP 155, GLY 14, SER 15, } \\
\text { GLY 159, TYR 338, GLY 157, } \\
\text { VAL 31, GLN 138, LYS } 337\end{array}$ & 4 & $\begin{array}{l}\text { LYS 19, ASN 17, } \\
\text { GLY 16, ASP } 158\end{array}$ & $\begin{array}{l}\text { LYS 19, ASN 17, GLY 16, ASP 158, } \\
\text { GLY 303, GLY 302, VAL 340, ASP } \\
\text { 155, GLY 14, SER 15, GLY 159, TYR } \\
\text { 338, GLY 157, VAL 31, GLN 138, } \\
\text { LYS } 337\end{array}$ \\
\hline $\begin{array}{l}\text { 2-pyridine carbonitrile, } \\
1,2,5,6\end{array}$ & -5.06 & $\begin{array}{l}\text { TYR 338, LYS 337, SER 142, } \\
\text { SER 301, ARG 336, GLY 302, } \\
\text { ASP 155, ASP 12, LYS } 19\end{array}$ & 3 & $\begin{array}{l}\text { TRP 341, SER } \\
339, \text { VAL } 340\end{array}$ & $\begin{array}{l}\text { TRP 341, SER 339, VAL 340, TYR } \\
\text { 338, LYS 337, SER 142, SER 301, } \\
\text { ARG 336, GLY 302, ASP } 155\end{array}$ \\
\hline
\end{tabular}

\section{CONCLUSION}

This research work concludes that the structure-based drug designing of molecules against virulent enzymes shows better inhibitory activity. The ligand compounds of Acacia catechu were docked against malarial enzyme Plasmodium falciparum. They were screened using the Lipinski rule of five and ADMET properties in which the compounds show various properties. The drugs were checked for activities, whether it breaches the blood-brain barrier as well as the central neuro system. Then the satisfied compounds were docked using Autodock software, in which the compounds like 9,12,15-octadecatrienoic acid has a higher affinity with $-7.95 \mathrm{Kcal} / \mathrm{mol}$ followed by phthalic acid, butyl 2pentyl ester - $7.35 \mathrm{Kcal} / \mathrm{mol}$ and Furo[2,3-d] pyrimidine-4,6 $[5 \mathrm{H}, 7 \mathrm{H}]$-dion $-6.24 \mathrm{Kcal} / \mathrm{mol}$. The inhibition of virulent enzyme leads to the discovery of novel drugs that can be used as a therapeutic agent after several trials. The comprehensive docking provides high accuracy studies. Hence, this research concludes that Acacia catechu has better inhibitor potential activity against malarial disease, and the bioactive compounds from Acacia catechu have better drug liking properties.

\section{REFERENCES}

1. Schmitz S, Grainger M, Howell S, Calder LJ, Gaeb M, Pinder JC, Holder AA, Veigel C. Malaria parasite actin filaments are very short. Journal of molecular biology. 2005 May 27; 349(1): 113-125.

2. Field SJ, Pinder JC, Clough B, Dluzewski AR, Wilson RJ, Gratzer WB. Actin in the merozoite of the malaria parasite, Plasmodium falciparum. Cell motility and the cytoskeleton. 1993; 25(1): 43-48.

3. Wesseling JG, Snijders PJ, van Someren P, Jansen J, Smits MA, Schoenmakers JG. Stage-specific expression and genomic organization of the actin genes of the malaria parasite Plasmodium falciparum. Molecular and biochemical parasitology. 1989 Jun 15; 35(2): 167-176.

4. Baum J, Tonkin CJ, Paul AS, Rug M, Smith BJ, Gould SB, Richard D, Pollard TD, Cowman AF. A malaria parasite formin regulates actin polymerization and localizes to the parasite-erythrocyte moving junction during invasion. Cell host \& microbe. 2008 Mar 13; 3(3): 188-198.

5. Sattler JM, Ganter M, Hliscs M, Matuschewski K, Schüler H. Actin regulation in the malaria parasite. European journal of cell biology. 2011 Nov 1; 90(11): 966-971.

6. Zhang Q, Huang Y, Zhang Y, Fang X, Claes A, Duchateau M, Namane A, Lopez-Rubio JJ, Pan W, Scherf A. A critical role of perinuclear filamentous actin in spatial repositioning and mutually exclusive expression of virulence genes in malaria parasites. Cell host \& microbe. 2011 Nov 17; 10(5): 451-463.

7. Saha MR, Dey P, Begum S, De B, Chaudhuri TK, De Sarker D, Das AP, Sen A. Effect of Acacia catechu (Lf) Willd. on oxidative stress with 
Abhishek Biswal R et al.

possible implications in alleviating selected cognitive disorders. PloS one. 2016 Mar 7; 11(3): e0150574.

8. Kaur K, Verma B, Kant U. Plants obtained from the Khair tree (Acacia catechu Willd.) using mature nodal segments. Plant cell reports. 1998 Mar 1; 17(5): 427-429.

9. Patel JD, Kumar V, Bhatt SA. Antimicrobial screening and phytochemical analysis of the resin part of Acacia catechu. Pharmaceutical biology. 2009 Jan 1; 47(1): 34-37.

10. Singh KN, Lal B. Notes on traditional uses of khair (Acacia catechu Willd.) by inhabitants of shivalik range in Western Himalaya. Ethnobotanical Leaflets. 2006; 2006(1): 12.

11. Saini ML, Saini R, Roy S, Kumar A. Comparative pharmacognostical and antimicrobial studies of acacia species (Mimosaceae). Journal of Medicinal Plants Research. 2008 Dec 31; 2(12): 378-386.

12. Ramesh, B., and Jayabharathi, V. Phytochemical Screening, HPTLC and GCMS Profile of Acacia catechu (L.f) Willd Hydroethanolic Leaf Extract. Int.J.Curr.Microbiol.App.Sci. 2017; 6(1): 82-94.

13. Webb SE, Fowler RE, O'shaughnessy C, Pinder JC, Dluzewski AR, Gratzer WB, Bannister LH, Mitchell GH. Contractile protein system in the asexual stages of the malaria parasite Plasmodium falciparum. Parasitology. 1996 May; 112(5): 451-457.

14. Aikawa M, Miller LH, Rabbege JR, Epstein N. Freeze-fracture study on the erythrocyte membrane during malarial parasite invasion. The Journal of cell biology. 1981 Oct 1; 91(1): 55-62.

15. Biswal AR, Mirunalini K, Jayshree P, Pazhamalai V. Molecular Docking Analysis of Bioactive Compounds of Acacia Concinna against Fungal Protein. Journal of Pharmaceutical Sciences and Research. 2019 Apr 1; 11(4): 1216-222.

16. Biswal A, Venkataraghavan R, Pazhamalai V. Molecular docking of various bioactive compounds from essential oil of Trachyaspermum ammi against the fungal enzyme Candidapepsin-1. Journal of Applied Pharmaceutical Science. 2019 May; 9(05): 2132.

17. Biswal A, Aishwariya A, Pazhamalai V. 2D QSAR, Admet Prediction And Multiple Receptor Molecular Docking Strategy In Bioactive Compounds Of Gracilaria Corticata Against Plasmodium Falciparum (Contractile Protein). Informatics in Medicine Unlocked. 2019 Jan 1; $17: 100258$

HOW TO CITE THIS ARTICLE: Biswal AR, Pazhamalai V. A Structure Based Molecular Docking of Acacia Catechu Against Contractile Protein Plasmodium

falciparum - A Malarial Disease. Int. J. Pharm. Sci. Drug Res. 2020;12(1):58-64. DOI: 10.25004/IJPSDR.2020.120110 